\title{
An Approach to Address Sexual Misconduct Through the Lessons Found in The Stories of Prophet Joseph and Prophet Lut in The Quran
}

Ahmad Murshidi Mustapha, Mohd Zahir Abdul Rahman, Mohd Miqdad Aswad Ahmad

To Link this Article: http://dx.doi.org/10.6007/IJARBSS/v11-i12/11861～DOI:10.6007/IJARBSS/v11-i12/11861

Received: 06 October 2021, Revised: 09 November 2021, Accepted: 28 November 2021

Published Online: 18 December 2021

In-Text Citation: (Mustapha et al., 2021)

To Cite this Article: Mustapha, A. M., Rahman, M. Z. A., \& Ahmad, M. M. A. (2021). An Approach to Address Sexual Misconduct Through the Lessons Found in The Stories of Prophet Joseph and Prophet Lut in The Quran. International Journal of Academic Research in Business and Social Sciences, 11(12), 1040-1051.

Copyright: (c) 2021 The Author(s)

Published by Human Resource Management Academic Research Society (www.hrmars.com) This article is published under the Creative Commons Attribution (CC BY 4.0) license. Anyone may reproduce, distribute, translate and create derivative works of this article (for both commercial and non0-commercial purposes), subject to full attribution to the original publication and authors. The full terms of this license may be seen at: http://creativecommons.org/licences/by/4.0/legalcode

Vol. 11, No. 12, 2021, Pg. 1040 - 1051

Full Terms \& Conditions of access and use can be found at http://hrmars.com/index.php/pages/detail/publication-ethics 


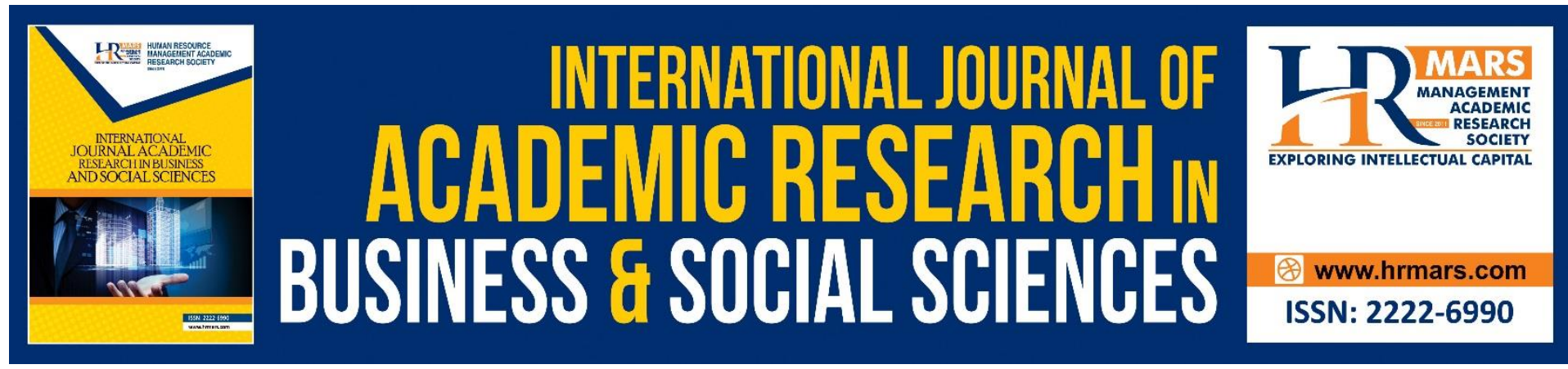

\title{
An Approach to Address Sexual Misconduct Through the Lessons Found in The Stories of Prophet Joseph and Prophet Lut in The Quran
}

\author{
Ahmad Murshidi Mustapha ${ }^{1}$, Mohd Zahir Abdul Rahman², Mohd \\ Miqdad Aswad Ahmad ${ }^{3}$ \\ ${ }^{1}$ Senior Lecturer, Academy of Contemporary Islamic Studies, Universiti Teknologi MARA \\ Cawangan Kelantan, ${ }^{2}$ Senior Lecturer, Faculty of Quran and Sunnah Studies, Universiti Sains \\ Islam Malaysia, ${ }^{3}$ Islamic Affairs Unit, Universiti Teknologi MARA Cawangan Kelantan \\ Email: ahmadmurshidi@uitm.edu.my
}

\begin{abstract}
Issues related to sexual misconduct have always been one of the factors causing breakdown of values and moral. This problem occurs not only in Malaysia, but in almost every country in the world. However, perspective on sexual misconduct might vary according to race, customs, and countries. Consequently, this study focuses on the issues of sexual misconduct from the Islamic perspective by evaluating them based on the Quranic sources in view of its relation with an element of maqāșid al-shari'ah, i.e. the Protection of Lineage, which has always been stressed in Islamic law. This study purports to identify the factors contributing to sexual misconduct during the time of Prophet Joseph and Prophet Luț, as well as emphasizing on the ways to solve these symptoms through ibrah (lessons) found in the Quran. Data collection is from secondary resources on the basis of literature studies and the collected data were analysed using content analysis. The findings showed five main factors of sexual misconduct; they are attraction towards physical appearance, seduction, existing opportunity, ignorance, and temptation of unnatural desire. The approach to address these issues involve outward methods such as giving advice and $d a^{\prime}$ wah (call toward God) in wise manner. While spiritually, dependency on Allah through prayers and tawakkul (reliance) is continually practised as the main basis of submission to Him. Such methods that have been utilized to address sexual misconduct are still relevant to be implemented and applied in our times, specifically in our country, in order to curb and curtail the problem as well as safeguard the well-being of the ummah and the nation.
\end{abstract}

Keywords: Approach, Sexual Misconduct, Prophet Joseph, Prophet Luț, Quran.

\section{Introduction}

Currently, the challenges of globalised world have given rise to many social issues that cross all walks of life, regardless of age. Knowledge and information channels are available in various forms and topics. Contributions of science and technology are immense and they provides input data for everyone. However, how one uses and understands the information received depends upon his application of knowledge, either for beneficial purpose or 
otherwise. This, in the end, will affect one's behaviour, character and moral. Alongside that, changes in character and moral are highly related to the application of education. According to Salleh (2008), education is a continuous process of moulding people toward a more meaningful life in the world and the hereafter. The result of education is when one obtains knowledge, and with that knowledge, he determines the values and beliefs that he will hold to, until they develop as a resolve. The determination that is based on the values of education pushes someone to act according to his duties and obligations as the vicegerent of Allah in this world.

Based on the Cabinet Committee Report 1979, the concept of education in Malaysia is aimed at promoting cultural, social, economic, and political development of the nation and the country as a whole. The purpose is to expedite and reinforce the ambitions of national unity, as well as creating a united, disciplined, and well-trained society in line with national development goals (Salleh, 2008). Sex education at school level is one of the factors that contributed to students' understanding of matters related to sex. Sex education refers to a formal course that teaches about human reproductive system, introduced in classrooms or at school. Sex education works as a tool of understanding oneself from sexual point of view and it made one aware about what has taken place in the course of his development from birth until adulthood (Salleh at el., 2006).

In relation to the above, sex education must be taught at all school levels so the correct perspective about sex can be delivered. Undeniably, the children and teenagers can explore these information through websites, but the concern arise whether they will be used correctly or otherwise, which in the end might cause harm to these younger generations. Other than that, as much as nine percent from total students in remove classes in the country is found to be sexually active (Razali, 2019). However, according to Arifin (2019), some parents are concerned about the application of sex education among children because to them, it is something inappropriate for discussion. Yet, the reality shows that sex education can address the symptoms of sexual misconduct because nowadays our children and teenagers are largely influenced by many prevailing trends such as online relationship, pornography, and delivery of obscene images electronically.

According to Chuan (2008), formal information regarding sex can only be found in science and biology textbooks. Meanwhile developed countries such as Singapore, Hong Kong, Britain, and United States has been teaching sex education for a considerable time since it can generally provide information on biological, psychological, and psychosocial changes resulting from human growth and development. Nevertheless, it cannot be denied that the awareness was also created by indirect conversation with peers or information obtained in the news which were channelled through mass media such as television, radio, Internet, newspapers, etc. Moreover among the teenagers, there are those who obtain information regarding sexuality from their friends, boyfriend/girlfriends, and also via pornography video channels (Rahman, 2020). Rhetorically, all parties in various situations did contribute information on sexuality here and around in the society, both formally and informally.

Subsequent to that, this study will identify the factors of sexual misconduct during the time of Prophet Joseph and Prophet Lut while exploring the approach used to address the problem. The definition of sexual misconduct in this discussion is the sexual relationships that fall 
outside the boundary of sharīah (Mohammed, 2007). The study will only focus on the situations occurred during the time of Prophet Joseph and Prophet Lut based on Quranic texts. The scope of the discussion is not merely limited to the occurrences themselves, but will also touch on the reasons why they happened, as well as the approaches that should be taken to solve the issues. To complement the study, the researchers collected secondary resources data based on some authoritative documents found during literature research. The obtained data will be analysed based on content analysis method.

\section{The Issues of Sexual Misconduct in The Quran}

The text of the Quran tells the story of Prophet Joseph and the temptation he faced. In addition, the Quran also crystallised the story of homosexual misconducts practised by people of Luț, the end of which was marked by disaster and wrath from Allah SWT. Due to that, the way Islam as a religion safeguards the purity of lineage becomes like an anchor of faith in protecting one's honour. It can be clearly seen from the words of Allah SWT in Surah alMu'minūn (The Believers) in the Quran:

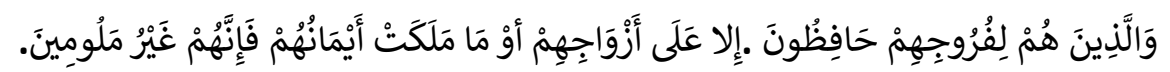

The meaning: "Except with those joined to them in the marriage bond, or (the captives) whom their right hands possess-for (in their case) they are free from blame".

The incident of sexual misconduct in the story of Prophet Joseph was caused by Zulaikha's seduction, recorded in Șurah Yūsuf, from verse 22 to verse 34. In these verses, the temptation towards prohibited sexual act was done by Zulaikha, wife to an Egyptian dignitary who tried to take advantage of Prophet Joseph. However, Allah SWT protected the honour of Prophet Joseph from being a victim of this sexual misconduct. Allah SWT said in Șurah Yūsuf:

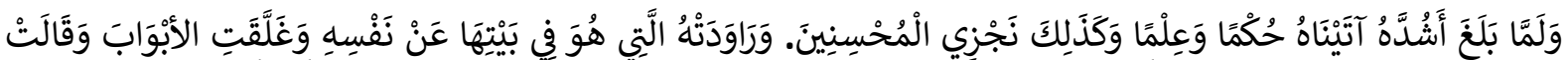

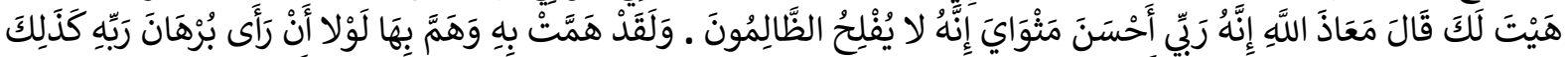

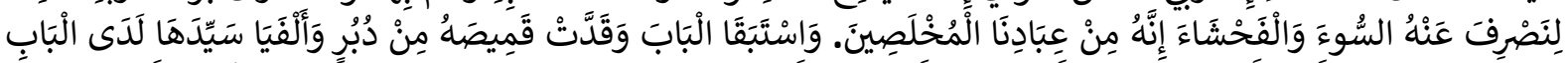

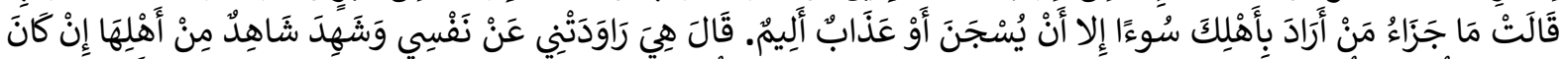



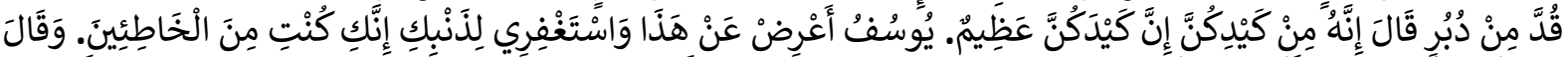

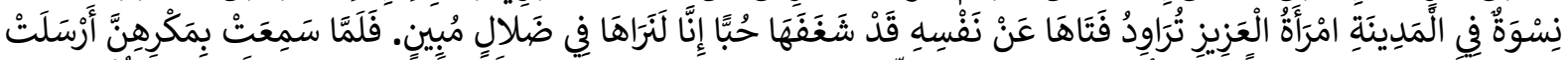

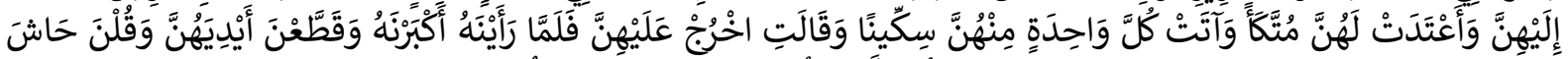



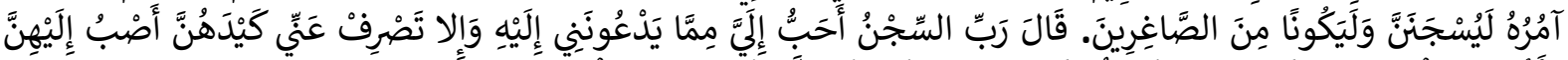

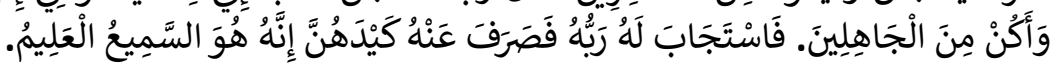

The meaning: "When Joseph attained his full manhood, We gave him power and knowledge: thus we do reward those who do right. But she in whose house he was, sought to seduce him from his (true) self: she fastened the doors, and said: 'Now come, you (dear one).' He (Joseph) said: 'Allah forbid! Truly your husband is my lord! He made my sojourn agreeable! Truly to no good come those who do wrong! And (with passsion) did she desire him, and he would have desired her, but that he saw the evidence of his Lord: thus (did We order) that We might turn away from him (all) evil and shameful deeds: for he was one of Our servants, sincere and purified. So they both raced each other to the door, and she tore his shirt from the back: they both found her lord near the door. She said: 'What is the (fitting) punishment for one who formed an evil design against your wife, but prison or a grievous chastisement?' He (Joseph) 
said: 'It was she that sought to seduce me-from my (true) self.' And one of her household saw (this) and bore witness, (thus) - 'If it be that his shirt is rend from the front, then is her tale true, and he is a liar. But if it be that his shirt is torn from the back, then is she the liar, and he is telling the truth!' So when he saw his shirt-that it was torn at the back-(her husband) said: 'Behold! It is a snare of you women! Truly, mighty is your snare! O Joseph, pass this over! ( $O$ wife), ask forgiveness for your sin, for truly you have been at fault!' Ladies said in the City: 'The wife of the (great) 'Aziz is seeking to seduce her slave from his (true) self: truly has he inspired her with violent love: we see she is evidently going astray.' When she heard of their malicious talk, she sent for them and prepared a banquet for them: she said (to Joseph): 'Come out before them.' When they saw him, they did extol him, and (in their amazement) cut their hands: they said: 'Allah preserve us! No mortal is this! This is none other than a noble angel!' She said: 'There before you is the man about whom you did blame me! I did seek to seduce him from his (true) self but he did firmly save himself guiltless!... And now, if he does not my bidding, he shall certainly be cast into prison, and (what is more) be of the company of the vilest!' He (Joseph) said: ' $O$ my Lord! The prison is more to my liking than that to which they invite me: unless You turn away their snare from me, I should (in my youthful folly) feel inclined toward them and join the ranks of the ignorant.' So his Lord hearkened to him (in his prayer), and turned away from him their snare: verily He hears and knows (all things)."

It must be understood that this sexual misconduct did not involve adultery between Prophet Joseph and Zulaikha. In fact, it was only an attempted adultery planned by Zulaikha to seduce Prophet Joseph. This situation shows that sexual advances and seducing someone to do an act that is prohibited by Islamic law can be categorised as sexual misconduct.

The sexual misconduct practised by people of Lut has also been recorded in the Quran, but its narration is available in multiple chapters. According to Wahbah (1998), the stories of Prophet Lut can be found in different chapters, some of them complemented the others. Narrating the abhorred misconduct of people of Luț, Allah SWT recorded in the Quran the words of Prophet Luț in Șurah al-A'raf, in God's own words:

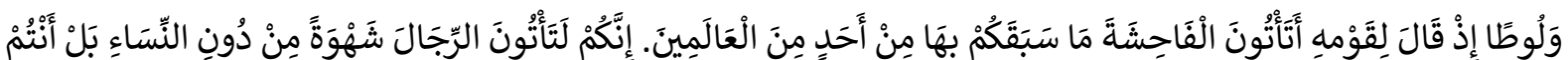

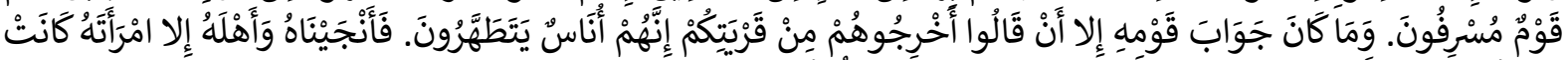

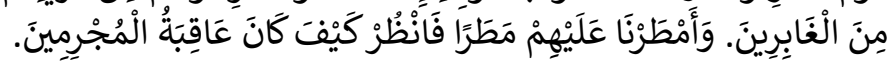

The meaning: "We also (sent) Luṭ: he said to his people: 'Do you commit lewdness such as no people in creation (ever) committed before you? For you practise your lusts on men in preference to women: you are indeed a people transgressing beyond bounds. And his people gave no answer but this: 'Drive them out of your city: these are indeed men who want to be clean and pure!' But we saved him and his family, except his wife: she was of those who lagged behind. And we rained down on them a shower (of brimstone): then see what was the end of those who indulged in sin and crime!"

According to Mutawali (2006), their action had been known to be wrong and vile, but to some people sometimes explanation is necessary and by that, it was further revealed in the next verse in these words of Allah, meaning: "For you practise your lusts on men in preference to women: you are indeed a people transgressing beyond bounds." These two verses reflected the position of Prophet Luț's people regarding their practices that went against human 
nature, who were created in pair. The men approach the same sex among them to fulfil their lust.

Nevertheless, the clear statement on the homosexuality of people of Lut found in the verse has yet another interpretation. Its interpretations is that people of Lut approached their wives in the manner prohibited by God, like the manner of a man when having intercourse with another man (Mutawali, 2006). Other than being involved in vile practices that went against human nature, people of Lut was also depicted in other verses with more actions that were frowned upon. Allah says in Șurah al-'Ankabut (The Spider), verse 29:

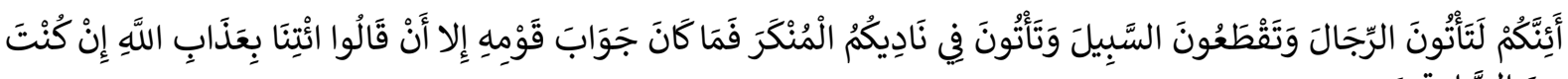
مِنَ الصَّادِقِيَن.

The meaning: "Do you indeed approach men, and cut off the highway? - and practice wickedness (even) in your councils? But his people gave no answer but this: "They said: Bring us the Wrath of Allah if you tell the truth".

There are differences of opinion regarding the issue of sexual misconduct among Prophet Luț's people, whether the practices only happened between men or also involve lesbians or female homosexuals. Several interpretation by the scholars of Islamic law concluded that there are two opinions regarding this issue; the first opinion holds that only gay homosexuality had taken place during that time. It was based on a number of Quranic commentaries that interpreted such verses as referring only to the practices of men approaching men, such as Tafsir Jalalayn, Tafsir al-Qurtubi, Tafsir Fi Zilal al-Quran, Tafsir Ibn Kathir and Tafsir al-Munir. While the second opinion stated that both gay and lesbian practices were already extant during that time. It was in line with the opinion of Ibn Abbas who said that people of Lut was the first ever that practises both gay and lesbian homosexuality.

\section{The Factors Contributing to Sexual Misconduct}

From the stories of Prophet Joseph and Prophet Lut in the Quran, some factors that contributed to sexual misconduct can be identified as follows:

\section{Attraction towards Physical Appearance.}

Prophet Joseph did not seduce Zulaikha with his desirable physical appearance, but his appearance was the reason Zulaikha was attracted to him. His beau, which left other women in awe too, was also depicted in verse 31 in Șurah Yūsuf, as it was revealed:



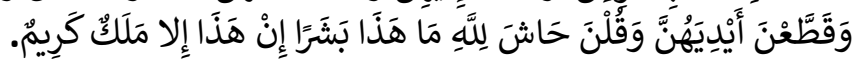
The meaning: "When she heard of their malicious talk, she sent for them: she gave each of them a knife: and she said (to Joseph): "Come out before them." When they saw him, they did extol him, and (in their amazement) cut their hands: they said, "Allah preserve us! No mortal is this! This is none other than a noble angel."

Moreover, he was depicted as a young man by His revealed words: 


\section{وَلَمَّا بَلَغَ أَشُدَّهُ آَتَيْنَاهُ حُكْمَا وَعِلْمًا وَكَذَلِكَ نَجْزِي الْمُحْسِنِينَ}

The meaning: "When Joseph attained his full manhood, We gave him power and knowledge: thus we do reward those who do right."

\section{Seduction}

The position of Prophet Joseph during that time was as a helper in the home of an Egyptian dignitary. The dignitary's wife, Zulaikha, always saw him doing house chores around and about her home. The presence of Prophet Joseph around the home was in the shoes of a victim as he was always within the eyesight of Zulaikha. And the matter had encouraged her to commit sexual misconduct towards Prophet Joseph to the extent of seducing and tempting him. It was portrayed in verse 23 of His revelation:

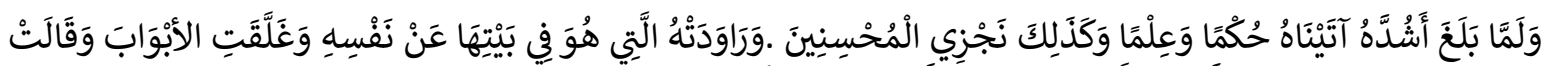

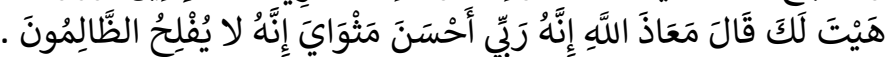

The meaning: "But she in whose house he was, sought to seduce him from his (true) self: she fastened the doors, and said: "Now come, you (dear one)." He (Joseph) said: "Allah forbid! Truly your husband is my lord! He made my sojourn agreeable! Truly to no good come those who do wrong!"

\section{Existing Opportunity}

If we delve further into the verse وَغَلَّقَتِ الأبْوَاب, which means: "fastened the doors", it can be clearly seen that the opportunity was wide open for Prophet Joseph. If Zulaikha's husband was with her, she would not dare to do it. Moreover, the next verse narrated that by coincidence, her husband arrived at the door, as revealed by Allah SWT:

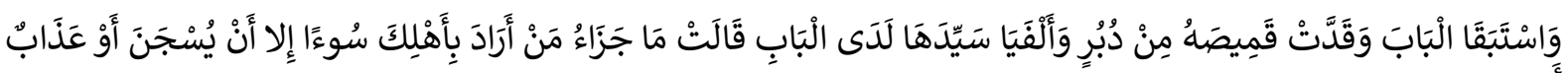

The meaning: "So they both raced each other to the door, and she tore his shirt from the back: they both found her lord near the door. She said: "What is the (fitting) punishment for one who formed an evil design against your wife, but prison or a grievous chastisement?"

\section{Ignorance}

In verse 55, from Șurah al-Naml, Allah SWT said:

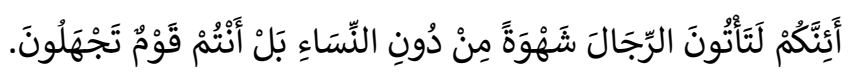

The meaning: "Would you really approach men in your lusts rather than women? Nay, you are a people (grossly) ignorant!"

The meaning of the verse showed the ignorance of the people of Lut when approaching men in their lusts. There are other commentaries on the meaning of 'ignorant' in the verse. If we look into the verse preceding it, Prophet Luț's people was portrayed as knowledgeable,


what is portrayed seems to be two contrary statements because if they are able to see the injustice, they must not be ignorant. Hence the word 'ignorant' mentioned in verse 55 did not bring the meaning of 'not knowing', but to signify foolishness, because the term 'ignorant' is an unbound expression (lafz al-muțlaq) (Mutawalli: 2006). 
5. Temptation of Unnatural Desire

The devil

enticed him to fulfil the desire and beautify and make

good the viles in his eyes.

The devil

enticed him to fulfil the desire and beautify it and make

good in his eyes.

The devil

enticed him to fulfil the desire and beautify it and make good the viles in his eyes.

The devil

enticed him to fulfil the desire and beautify it and make good the viles in his eyes.

The impulse to fulfil the desire is the work of the devil and they beautify and make good the vile in the eyes of those who committed it (Ahmad, Mustafa \& Shah, 2008). People of Lut were no longer attracted to their wives, so they chose to indulge in the unnatural and vile practices. It can be seen in verse 166, in Șurah al-Shu'arā', through His revelation:

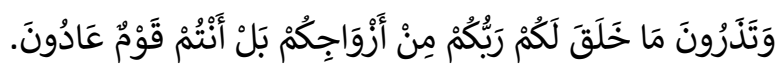

The meaning: "And leave those whom Allah has created for you to be your mates? Nay, you are a people transgressing (all limits)!"

In Șurah Hud, verse 79, it is clear they were no longer interested in their wives, and they acknowledge it by their own words as provided below:

The meaning: "They said: 'Well do you know we have no need of your daughters: indeed you know quite well what we want!"'

These five factors are stated in the Quran through the stories of Prophet Joseph and Prophet Lut. The factors appear to be both external and internal. Attractive physical appearance, seduction, and existing opportunity are the external factors that prompted the sexual misconduct, while ignorance and desire were the internal factors affecting the wrongdoer.

\section{The Approach in Addressing the Issues of Sexual Misconduct}

The methods of da'wah (call towards God) was taught both in theory and practice by Rasulullah SAW to his followers, covering every nuances of life. Advices from the Quran also call towards uprightness in a wise manner. The basic pillar of the methods of $d a^{\prime} w a h$ can be found in the words of Allah SWT in Șurah al-Nahl, verse 125:



The meaning: "Invite (all) to the Way of your Lord with wisdom and beautiful preaching: and argue with them in ways that are best and most gracious."

Wisdom cannot be simply interpreted into gentle manners, but must be extended beyond that based on the situations and circumstances of the invitees. The wisdom demonstrated by 
both Prophet Joseph and Prophet Lut can be taken as one of the methods that can be used in da'wah today. The methods of rebuke or aa as exemplified by the Qur'an are various and among them are al-Nazhar, al-Tafakkur, al-Tadhakkur, al-'Ilm, al-'Aql and so on (Abu Bakr Ali, 2004). Among the approaches used by both of them are:

\section{Al-Isti'ādhah (Praying for Protection)}

When Prophet Joseph was seduced by Zulaikha, he prayed with the expression "معاذ الله that means "I seek the protection of Allah". The initial response given was not in the form of violence or anger, but directly in remembrance of God, as a self-protection from being further tempted by the devil towards such an act. In this context, Prophet Joseph initiated the factor of self-faith as a bulwark of prevention and control from the temptations of Zulaikha. Such a situation can also be found in a hadith of the Prophet SAW which describes that the initial fortification from the vices of adultery must start chiefly from oneself, which leads to success in the hereafter. In the hadith of Rasulullah SAW related to the group that will be protected by Allah in the hereafter, among them are men who fear Allah when seduced by women:

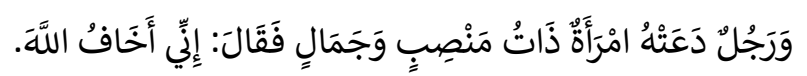

The meaning: "And a man who is invited by a woman of appearance to commit adultery, then it is said to her 'I fear God'".

\section{Al-Tadhakkur (Delivering Admonition)}

Delivering the admonitions is one of the duties of the apostle towards his people. Every mistake and deviation that happens needs to be admonished in wise manner. The duty of an apostle is to spread the message and beautify the morals of his people. They cannot remain silent with the disobedience that is happening in their midst and this is their responsibility and the responsibility of all their followers.

After fortifying himself with the protection and remembrance of Allah, Prophet Joseph awakened Zulaikha by reminding her of his husband's kind treatment towards him. Prophet Joseph tried to create guilt in Zulaikha and himself, reminding that if the act took place then it amounted to his showing ingratitude and disrespect to his own master. After he was kindly treated and cared for, not only he would fail to reciprocate the kindness, but also break his master's trust in a very insolent way. His own words were recorded in the Quran as such, in Șurah Yūsuf:

The meaning: "He made my sojourn agreeable!

$$
\text { إِنَّهُ رَبِّي أَحْسَنَ مَثْوَايَ. }
$$

Prophet Lut gave out similar response regarding the vices of his own people. Appropriate admonitions were delivered to steer them away from the vices. Among his warnings to them were:

i. Reminding them of their lawfully wedded wives as revealed in the words of Allah SWT in Șurah Hud verse 78:

The meaning: "Luț said: "O my people! Here are my daughters: they are purer for you (if you marry)!". 
ii. Reminding them to fear Allah as Prophet Luț advised his people in Șurah Hud, verse 78:

The meaning: "Now fear Allah".

\section{Sincerity}

The care and protection received by the apostles was the result of their sincere obedience to God. Allah SWT revealed:

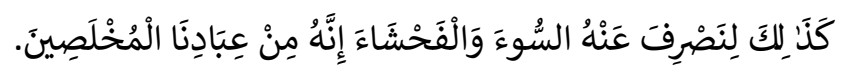

The meaning: "Thus (did We order) that We might turn away from him (all) evil and shameful deeds: for he was one of Our servants, sincere and purified."

In this context, as long as ones maintain their obedience towards Allah, Allah gives assurance that He will protect His servants. Thus, the factor of faith is one of the main pillars in fortifying oneself from vices.

4. Al-'Uzlah (Seeking Solitude)

Eventually, the truth behind the incident that occurred between Prophet Joseph and Zulaikha came to surface through logical evidence in favour of Prophet Joseph. In order to dismiss the accusations and keep the slander from spreading, he chose to be imprisoned and separated from the onslaught of vilification by the society. Allah SWT revealed:

$$
\text { قَالَ رَبِّ السِّجْنُ أَحَبُّ إِلَيَّ مِمَّا يَدْعُونَنِي إِلَيْهِ. }
$$

The meaning: "He (Joseph) said: O God! The prison is more to my liking than that to which they invite me."

\section{Invocation}

Reliance to Allah is expressed through one of the prayers of Prophet Lut towards his Creator. Allah says in Șurah al-'Ankabut (The Spider), verse 30.

$$
\text { قَالَ رَبِّ انْصُرْنِي عَلَى الْقَوْمِ الْمُفْسِدِينَ. }
$$

The meaning: "He said: 'O My Lord! Help You me against people who do mischief?'

According to Wahbah (1998), it was not unusual for the Prophets AS to ask destruction of his disbelieving people, as prayed by Prophet Noah: "And Noah, said: 'O my Lord! Leave not of the Unbelievers, a single one on earth! For, if you do leave any of them, they will but mislead Your devotees, and they will breed none but wicked ungrateful ones."

\section{Reprimanding by Application of Istifhām Inkārī}

Among the method of da'wah applied by the apostles is the uslub of da'wah. Istifham inkari is a question asked in the nature of denial and the answer to the inquiry is 'no'. The question asked by Prophet Lut to his people, as portrayed in Șurah Al-A'raf, verse 80 is as follows:

$$
\text { أَتَاتُتُونَ الْفَاحِشَةََ مَا سَبَقَكُمْ بِهَا مِنْ أَحَحِد مِنَ الْعَالَمِينَ. }
$$

The meaning: "Do you commit lewdness such as no people in creation (ever) committed before you?" 
The answer to such question must be 'no' because the right mind would definitely deny the accursed act they had committed (Mutawali: 2006).

The approach shown by Prophet Joseph and Prophet Lut in handling the symptoms of sexual misconduct covers the external aspects, taking the form of da'wah through appropriate reprimands and advices. At the same time, the spiritual aspect involving submission and reliance to Allah SWT continues to be the main objective in facing such situation.

\section{Conclusion}

The prevalence of such misconduct in society requires a wise and effective solution. Religious approach is necessary in all aspect of solution to problems either spiritual or physical. The effectiveness of each method applied depends on the circumstances and situations at hands. Hence, knowledge is the main necessity and faith is the pillar of self-control to avoid involvement in any sexual misconduct and such.

The methods used by the prophets AS are among the examples that should be emulated, while at the same time adapting and enhancing them to suit the necessities of our time. Actions that deemed to be appropriate in current time such as legal actions may also be effective in controlling and eradicating the symptoms that are corrupting the nation. Morals and characters of each nation reflect the civilizational values of that country. Consequently, the society must be governed in the right way as they are deemed human capital towards establishing a nation of high moral values and rich with gratitude and ability as well as possessing the right mindset.

\section{Corresponding Author}

Ahmad Murshidi Mustapa

Universiti Teknologi MARA (UiTM), Kelantan Branch, 18500 Machang, Kelantan.

Email: ahmadmurshidi@uitm.edu.my

\section{References}

Al-Siddiq, A. B. A. (2004). Manhaj al-Quran fi Tahzib Ghazair al-Insan Ghaziratu Hubbi alIstithla', Majallah al-Syariah wa al-Dirasah al-Islamiah. Jamiah al-Kuwait.

Salleh, A. M. (2008). Pengajian Agama Islam dan j-QAF, Metodologi dan Pedagogi Pendidikan. Oxford Fajar Sdn. Bhd.

Al-Ansari, M. A. (n.d.). Al-Jami' li al-Ahkam al-Quran al-Karim Tafsir al-Qurtubi. Maktabah alIman.

Mohammed, S. A. (2007). Al-A'wamil al-Waqia'h li al-Syabab min al-inhiraf al-Jinsiyyah Istinbatan min Qissah Joseph a'laihi al-Salam, Majallah al-Syariah wa al-Dirasah alIslamiah. Jamiah al-Kuwait.

Al-Zuhaily, W. (1998). Al-Tafsir al-Munir fi al-A'qidah wa al-Syaria'h wa al-Manhaj, Beirut: Dar al-Fikr.

Cheong, P. C. (2008). Persepsi Pelajar Terhadap Pendidikan Seks di Sekolah: Satu Tinjauan di Kalangan Pelajar Tahun 4, Fakulti Pendidikan, UTM, Skudai, Academic Report. Universiti Teknologi Malaysia.

Salleh, H., Din, C. R. C., \& Kadir, R. (2006). Pendidikan Seksual Dalam Menangani Permasalahan Seksual Mahasiswa Di IPT: Satu Tinjauan Kaunseling. Paper presented 
at National Student Development Conference (NASDEC) 2006, 8-9 August 2006, Kuala Lumpur, Malaysia.

IbnKathir. (n.d.). Tafsir al-Quran al-A'zim Ibn Kathir. Dar Misr li al-Thaba'ah.

IbnKathir, al-Mahalli \& al-Suyuti. (n.d.). Tafsir al-Quran al-A'zim al-Jalalain, Matba'ah bin Halabi.

Arifin, L. (2019). https://www.bharian.com.my/rencana/agama/2019 /01/523906/terapkanpendidikan-seks-ikut-kerangka-islam. Accessed on 30 August 2021.

Ahmad, R., Mustafa, M. S., \& Shah, M. A. (2008). Punca, Kesan Dan Langkah Untuk Menangani Tingkah Laku Seksual Pelajar Mengikut Pendekatan Kaunseling Islam. Paper presented at Konvensyen Pendidikan Nasional 2008, Fakulti Sains Kognitif Dan Pembangunan Manusia. Universiti Perguruan Sultan Idris.

Razali, S. A. (2019). https://www.bharian.com.my/berita/pendidikan/ 2019/01/518350/2kementerian-bincang-mengenai-pendidikan-seks. Accessed on 5 September 2021.

Rahman, S. F. A. (2020). Memperkasa Anak-Anak Dengan Pendidikan Seksual: Satu Model Islami. Jurnal Dunia Pengurusan, Asian Scholars Network (ASNet). Bil. 2, No. 1.

Sya'rawi, M. M. (2006), Qișaș al-anbiya'. Dar al-Quds. 